\title{
Effect of Zinc and Bio Fertilizers on Antioxidant Enzymes Activity, Chlorophyll Content, Soluble Sugars and Proline in Triticale Under Salinity Condition
}

\author{
Younes KHEIRIZADEH AROUGH, Raouf SEYED SHARIFI*, Mohammad SEDGHI, \\ Morteza BARMAKI
}

University of Mohaghegh Ardabili, Faculty of Agricultural Sciences, Department of Agronomy and Plant Breeding, Daneshgah Street, Ardabil, Iran; Kheirizadeh@yahoo.com; Raouf_sharifi@yahoo.com(*correspondingauthor);Mosedghi2003@yahoo.com;Barmakimorteza@gmailcom

\begin{abstract}
In order to study the effects of bio fertilizers and zinc fertilizer on antioxidant enzymes activity, chlorophyll content, soluble sugars and proline in triticale under salinity condition, a factorial experiment was conducted based on randomized complete block design with three replications under greenhouse condition. Experiment factors were included salinity in four levels [no-salt (control or $S_{0}$ ), salinity $20\left(S_{1}\right), 40\left(S_{2}\right)$ and $60\left(S_{3}\right) \mathrm{mM} \mathrm{NaCl}$ ) equivalent of 1.85, 3.7 and $5.55 \mathrm{dS} \mathrm{m}^{-1}$ respectively], four bio fertilizers levels (no bio fertilizer $\left(\mathrm{F}_{0}\right)$, application of mycorrhiza $\left(\mathrm{F}_{1}\right)$, PGPR $\left(\mathrm{F}_{2}\right)$, both application PGPR and mycorrhiza $\left(\mathrm{F}_{3}\right)$ and three nano zinc oxide levels (without nano zinc oxide as control $\left(\mathrm{Zn}_{0}\right)$, application of 0.4 $\left(\mathrm{Zn}_{1}\right)$ and $\left.0.8\left(\mathrm{Zn}_{2}\right) \mathrm{g} \mathrm{lit}{ }^{-1}\right)$. Results showed that salinity severe stress $(60 \mathrm{mM})$ decreased chlorophyll $a$, chlorophyll $b$, total chlorophyll, carotenoid and grain yield of triticale, whereas soluble sugars and proline content, the activities of Catalase (CAT), Peroxidase (POD) Polyphenol Oxidase (PPO) enzymes increased. Results showed that both application of bio fertilizer and $0.8 \mathrm{~g} \mathrm{lit}^{-1}$ nano zinc oxide $\left(\mathrm{F}_{3} \mathrm{Zn}_{2}\right)$ increased about $39 \%$ from grain yield in comparison with $\mathrm{F}_{0} \mathrm{Zn}_{0}$ under the highest salinity level. Based on the results, it was concluded that bio fertilizers and nano zinc oxide application can be recommended for profitable triticale production under salinity condition.
\end{abstract}

Keywords: catalase, grain yield, mycorrhiza, peroxidase, plant growth promoting rhizobacteria, polyphenol oxidase

\section{Introduction}

Triticale is a human-made crop, being a hybrid by crossfertilization of wheat (Triticum spp.) and rye (Secale spp.). In general, triticale combines the high yield potential of wheat with the biotic and abiotic stress tolerance of rye, making it more suitable for the production in marginal areas (acidic, saline, or soils with heavy metal toxicity) (Cantale et al., 2016).

Salinity is one of the major abiotic environmental stresses, which affect almost every aspect of plant life and significantly reduces crop yield in affected areas (Yamaguchi and Blumwald, 2005). Thus it is a serious threat to agricultural productivity especially in arid and semiarid regions (Parvaiz and Satyawati, 2008). Salinity stress is known to affect many physiological activities related to the accumulation of ions and osmolytes such as proline (Lee et al., 2008). The response of plants to salinity depends on several factors such as developmental stage, severity, duration of stress, and cultivar genetics. Salinity also causes oxidative damage as a consequence of producing large amounts of reactive oxygen species (ROS) in different cell organelles (Foyer and Shigeoka, 2011). The induction of ROS-scavenging enzymes, such as SOD, POD, APX, CAT (Mitter, 2002) and other compounds such as carotenoids (Burke and Mahan, 1991), soluble protein (Sinha et al., 2005) is the most common mechanism for detoxifying ROS synthesized during stress responses. The antioxidant system plays an important role in plant tolerance against stress conditions and high concentrations of these antioxidative enzymes have been reported in tolerant species compared to sensitive ones (Gill and Tuteja, 2010).Jin et al. (2009) reported that salt stress increased POD activity in barley genotypes differing in salt tolerance. Nadeem et al. (2006) reported that salt stress decreased chlorophyll pigments ( $a, b$ and carotenoids contents) of maize, but inoculation with bio fertilizers increased the chlorophyll pigments. Several strategies have been developed in order to decrease the toxic effects caused by high salinity on plant growth, among them use of bio fertilizers such as mycorrhiza and plant growth promoting rhizobacteria (PGPR) plays important role in yield improvement of plants (Dimkpa et al., 2009). 
Dimkpa et al. (2009) reported that rhizosphere microorganisms, exclusively beneficial bacteria and fungi, can improve plant performance under stress environments and enhance yield. The use of PGPR may be proper in developing strategies to facilitate plant growth in saline soils (Vessy, 2003). PGPR can facilitate plant growth indirectly by reducing plant pathogens, or directly by facilitating the uptake of nutrients from the environment, by influencing phytohormone production (e.g. auxin, cytokinin and gibberellins) and production of siderophores (Kohler et al., 2006). Mycorrhiza is a symbiotic association between plant roots and fungi. Arbuscular mycorrhizal fungi promote salinity tolerance by utilizing various mechanisms such as accumulation of compatible solutes (Evelin $e t a l ., 2013$ ) and production of higher antioxidant enzymes (Manchanda and Garg, 2011). Mycorrhizal fungi increase the sugar content of the host plant by hydrolysis of starch to sugars and preventing structural changes in soluble protein (Kapoor et al., 2013). Researchers have showed that AM fungi can improve plant tolerance to drought and salinity stress (Gamalero $e t$ al., 2009). Plants infected with IAA-overproducing PGPR strains showed high antioxidant enzyme activities that contribute to enhance plant protection against salt stress (Bianco and Defez, 2009). Inoculation barley plants with Pseudomonas sp. could compensate the salt effects and improve plant development through enhanced production of proline, chlorophyll pigment and soluble sugars and increase dry biomass (Hmaeid et al., 2014). Using biologic fertilizers such PGPR can increase quantity and quality of crop yield, efficiency of chemical fertilizers and tolerance of salt and drought stresses as one of the suitable ways to adapt to environment (Arzanesh et al.,2009).

Zinc is an essential micronutrient for humans, animals and plants, which act either as the metal component of enzymes or as a functional structural or a regulatory co-factor of a large number of enzymes. A number of researchers have reported the essentiality and role of zinc for plant growth and yield (Fageria et al., 2002). Zinc is required for chlorophyll production, pollen function, fertilization and germination and plays an important role in biomass production (Cakmak, 2008). Ebrahimian and Bybordi (2011) suggested that foliar application of zinc activated enzymes involved in reactive oxygen species detoxification and accumulation of proline in sunflower under salt stress conditions.

A better understanding of physiological responses under salinity may help in programs which the objective is to improve the salt tolerance of crop. During the course of these stresses, active solute accumulation of compatible solutes such as proline and the activities CAT, POD and PPO enzymes are claimed to be an effective stress tolerance mechanism. Therefore, the aim of this study was to evaluate the effects of bio fertilizers and zinc on some the physiological responses (i.e., antioxidant enzyme activity, chlorophyll, protein, soluble sugars and proline) of triticale under salinity stress conditions.

\section{Materials and Methods}

\section{Experimental design}

A factorial experiment based on randomized complete block design with three replications was conducted under greenhouse condition in 2014. Factors experiment were included salinity in four levels [no-salt (control or $\left.S_{0}\right)$, salinity $20\left(S_{1}\right), 40\left(S_{2}\right)$ and 60 $\left(\mathrm{S}_{3}\right) \mathrm{mM} \mathrm{NaCl}$ ) equivalent of $1.85,3.7$ and $5.55 \mathrm{dS} \mathrm{m}^{-1}$ respectively], four bio fertilizers levels (no bio fertilizer $\left(\mathrm{F}_{0}\right)$, application of mycorrhiza $\left(\mathrm{F}_{1}\right)$, PGPR $\left(\mathrm{F}_{2}\right)$, both application PGPR and mycorrhiza $\left(\mathrm{F}_{3}\right)$ and three nano zinc oxide levels (without nano zinc oxide as control $\left(\mathrm{Zn}_{0}\right)$, application of 0.4 $\left(\mathrm{Zn}_{1}\right)$ and $0.8\left(\mathrm{Zn}_{2}\right) \mathrm{g}$ lit $\left.{ }^{-1}\right)$. Mycorrhiza fungi (Glomus mosseae) was purchased from the Zist Fanavar Turan institute and soils were treated based on the manufacturer's protocol $10 \mathrm{~g}$ of inoculums per $1 \mathrm{~kg}$ soil, each pot containing approximately 790 spores.

Psedomunas putida strain 186 and Azotobacter chrocoococum strain 5 were isolated from the rhizospheres of wheat by Research Institute of Soil and Water, Tehran, Iran. For inoculation seeds were coated with gum Arabic as an adhesive and rolled into the suspension of bacteria until uniformly coated (Seyed Sharifi and Khavazi, 2011). The strains and cell densities of micro organisms used as PGPR in this experiment were $10^{7}$ colony forming units (CFU).

The soil was silty loam, with $\mathrm{pH}$ about 6.9. Air temperature ranged from $23-26^{\circ} \mathrm{C}$ during the day and $18-20^{\circ} \mathrm{C}$ during the night. Humidity ranged from $60-65 \%$. The triticale cultivar 'Joanilo' was used in the experiment. Optimal density of cultivar 'Joanilo' is 400 seeds $\mathrm{m}^{-2}$, so forty seeds of triticale were sown in each pot with $4 \mathrm{~cm}$ deep. The pots were immediately irrigated after planting. Salt stress treatments were applied 18 days after planting (at 2-3 leaf stage). Nano zinc oxide was with the average of particle size less than $30 \mathrm{~nm}$ and special surface of particle more than $30 \mathrm{~m}^{2} \mathrm{~g}^{-1}$. Nano zinc oxide powder added to deionized water and was placed on ultra sonic equipment $(100 \mathrm{w}$ and 40 $\mathrm{kHz}$ ) on a shaker for better solution (Prasad et al., 2012). Foliar application with nano zinc oxide was done in two stage of period growth (4-6 leaf stage and before of booting stage).

\section{Catalase assay}

To measure the enzyme activity, $0.2 \mathrm{~g}$ of fresh tissue was used. In order to extract protein, $0.2 \mathrm{~g}$ of plant fresh tissue was crushed by using liquid nitrogen and then one ml of buffer Tris- $\mathrm{HCl}(0.05 \mathrm{M}$, $\mathrm{pH}=7.5$ ) was added. Obtained mixture centrifuged for $20 \mathrm{~min}$ $\left(13,000 \mathrm{rpm}\right.$ and $\left.4{ }^{\circ} \mathrm{C}\right)$, then supernatant was used for enzyme activity measurements (Sudhakar et al., 2001). Catalase activity was assayed according to Karo and Mishra (1976). The $60 \mu \mathrm{L}$ protein extract was added to Tris buffer $(50 \mathrm{mM}, \mathrm{pH}=7)$ containing 5 $\mathrm{mM} \mathrm{H}_{2} \mathrm{O}_{2}$ on the ice bath, then the absorbance curve was plotted at a wavelength of $240 \mathrm{~nm}$. Enzyme activity was obtained for OD ugprotein min $^{-1}$ of fresh tissue.

\section{Peroxidase assay}

Peroxidase activity measured as explained by Karo and Mishra (1976): $50 \mu \mathrm{l}$ protein extract was added to $2.5 \mathrm{ml}$ extraction buffer containing $100 \mu \mathrm{M}$ Tris buffer $100 \mathrm{mM}$ and hydrogen peroxide $5 \mathrm{mM}$ and $10 \mathrm{mM}$ Pirogalol in the ice bath and absorbance changes was read at a wave length of $425 \mathrm{~nm}$ graph. Enzyme activity was obtained for OD $\mu \mathrm{g}$ protein $\mathrm{min}^{-1}$ of fresh tissue.

\section{Polyphenoloxidase assay}

Enzyme activity was measured by Karo and Mishra (1976) method: $100 \mu \mathrm{l}$ protein extract was solved in $1.5 \mathrm{ml}$ Tris $0.2 \mathrm{M}$ and $0.3 \mathrm{ml}$ Pirogalol $0.02 \mathrm{M}$ and the resulting composition was placed in the bain marie bath at $25^{\circ} \mathrm{C}$ for five minutes and then the absorbance at $420 \mathrm{~nm}$ was recorded. Enzyme activity was obtained for OD $\mu \mathrm{g}$ protein $\mathrm{min}^{-1}$ of fresh tissue. Also, the evaluation of protein carried out by Bradford (1976) method, $0.2 \mathrm{~g}$ of plant tissue was squashed with $0.6 \mathrm{ml}$ extraction buffer and was centrifuged at $11,500 \mathrm{rpm}$ for 20 minutes at $4{ }^{\circ} \mathrm{C}$. The 
118 supernatant was transferred to the new tubes and centrifuged for 20 minutes at $4,000 \mathrm{rpm}$. To measure the protein amount, $10 \mu \mathrm{l}$ of obtained extract was added to $5 \mu \mathrm{l}$ Bradford solution and $290 \mu \mathrm{l}$ extraction buffer and the absorbance rate was read at $595 \mathrm{~nm}$.

\section{Photosyntheticpigment content}

Chlorophyll content measured in $0.2 \mathrm{~g}$ fresh leaf tissue, which gradually worn with $80 \%$ acetone and the solution volume was brought $20 \mathrm{ml}$ using acetone $80 \%$. Then it was centrifuged for 10 minutes at $400 \mathrm{rpm}$ and the absorbance at 645,663 and $470 \mathrm{~nm}$ was recorded by a spectrophotometer. Chlorophyll and carotenoids were obtained based on the following equations (Arnon, 1949):
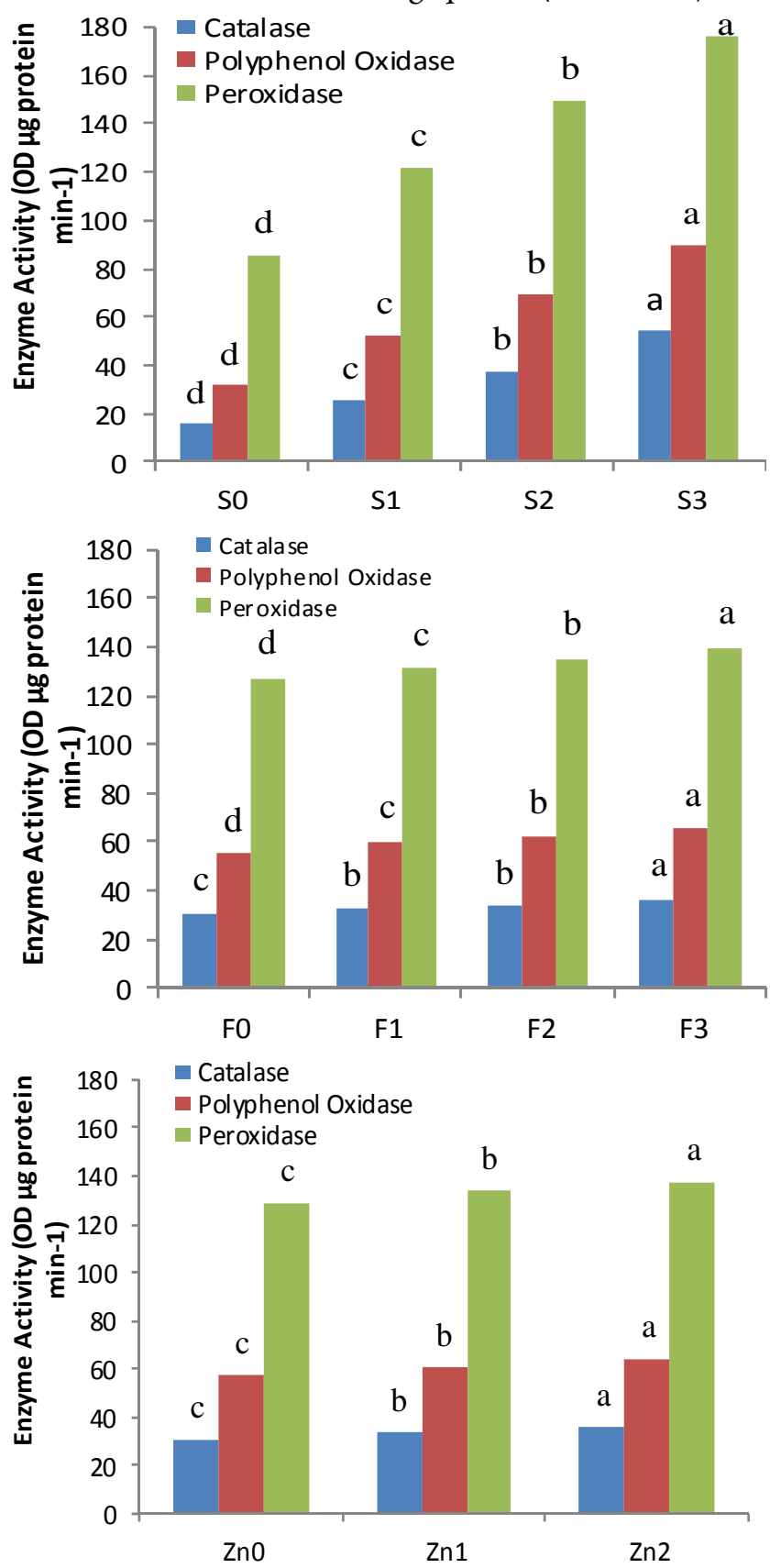

Fig. 1. Effect of salinity, bio fertilizers and nano zinc oxide on CAT, PPO and POD activity of triticale; $S_{0}, S_{1}, S_{2}$ and $S_{3}$ are no-salt (control), salinity 20, 40 and $60 \mathrm{mM}$ $\mathrm{NaCl}$ ), respectively. $\mathrm{F}_{0}, \mathrm{~F}_{1}, \mathrm{~F}_{2}$ and $\mathrm{F}_{3}$ are no bio fertilizer, application of mycorrhiza, PGPR, both applications PGPR and mycorrhiza respectively. $Z_{n_{0},}, \mathrm{Zn}_{1}$ and $\mathrm{Zn}_{2}$ are without nano zinc oxide as control, application of 0.4 and $0.8 \mathrm{glit}^{-1}$ respectively
Chlorophyll $a=(19.3 \times \mathrm{A} 663-0.86 \times \mathrm{A} 645) \mathrm{V} / 100 \mathrm{~W}$

Chlorophyll $b=(19.3 \times \mathrm{A} 645-3.6 \times \mathrm{A} 663) \mathrm{V} / 100 \mathrm{~W}$

Total Chlorophyll $=$ Chlorophyll $a+$ Chlorophyll $b$

Carotenoid $=\left(1000 \mathrm{~A} 470-1.82 \mathrm{C}_{a}-85.02 \mathrm{C}_{b}\right) / 198$

\section{Proline assay}

In order to measure proline, $0.5 \mathrm{~g}$ of plant fresh tissue was crushed in $10 \mathrm{ml}$ sulpho acetic acid solution to obtain a homogeneous mixture. Then, the solution was smoothed using whit-man and $2 \mathrm{ml}$ dimenhydrinate reagent and $2 \mathrm{ml}$ glacial acetic acid were added. The extract was mixed and stirred on bain-marie at $100{ }^{\circ} \mathrm{C}$ for one hour and then $4 \mathrm{ml}$ toluene added and the extract was vortexed to form two separate phases. The supernatant was read at $520 \mathrm{~nm}$ by a spectrophotometer (Bates et al., 1973). Soluble sugars were extracted from flag leaf using the modified phenol-sulphuric acid method (Dubois et al., 1956).

In order to measure grain yield per plant, 10 plants of each pot randomly were harvested.

\section{Statistic analysis}

Analysis of variance and mean comparisons were performed using SAS computer software packages. The main effects and interactions were tested using the least significant difference (LSD) test.

\section{Results and Discussion}

\section{Activity of CAT, POD and PPO enzymes}

Results indicated that salinity stress, bio fertilizers and nano zinc oxide had a significant effect on the activities antioxidant enzymes. The activity of CAT, POD and PPO enzymes were increased with the increase of salinity stress, application of bio fertilizers and nano zinc oxide in comparison with control. The highest activity of CAT (54.29, 36.55 and 35.64 OD $\mu \mathrm{g}$ protein $\left.\mathrm{min}^{-1}\right)$, PPO (89.53, 65.16 and 64.23 OD $\mu \mathrm{g}$ protein $\mathrm{min}^{-1}$ ) and POD (176.26, 139.83 and 137.54 OD $\mu \mathrm{g}$ protein $\mathrm{min}^{-1}$ ) were observed in salinity of $S_{3}$, application bio fertilizers as $\mathrm{F}_{3}$, nano zinc oxide as $\mathrm{Zn}_{2}$ respectively (Fig. 1). The lowest of CAT (15.59, 30.83 and $30.91 \mathrm{OD} \mu \mathrm{g}$ protein $\left.\mathrm{min}^{-1}\right), \mathrm{PPO}(31.47,54.91$ and 57.28 OD $\mu$ g protein $\left.\mathrm{min}^{-1}\right)$ and POD activity $(85.89,127.31$ and $128.79 \mathrm{OD} \mu \mathrm{g}$ protein $\mathrm{min}^{-1}$ ) were obtained at no-salinity, no bio fertilizers and without nano zinc oxide (Fig. 1). Abdel Latef (2011) suggested that plants develop self defense mechanisms by producing antioxidant enzymes like superoxide dismutase, ascorbate peroxidase and catalase. A continued increase in CAT, PPO and POD activity might indicate that these enzymes are a major enzymes detoxifying hydrogen peroxide in triticale under salinity stress.

Our results dictated that there was an increase about $18.5 \%$, $15.7 \%$ and $9.8 \%$ in activity of CAT, PPO and POD, respectively with bio fertilizer application as $\mathrm{F}_{3}$ in comparison with $\mathrm{F}_{0}$. Belimov et al. (2009) have reported beneficial effects of PGPR for improving plant growth under normal as well as stressful environment. Gamalero et al. (2009) showed that bio fertilizers such as mycorrhiza protect the plants from reactive oxygen species produced under stress conditions.

The impact of nano zinc oxide on activity of CAT and PPO and POD were similar to bio fertilizers. So, there was an increase about $15.3 \%, 12.1 \%$ and $6.7 \%$ in activity of CAT, PPO and POD, respectively by nano zinc oxide foliar spraying as $\mathrm{Zn}_{2}$ in comparison with $\mathrm{Zn}_{0}$ (Fig. 1).Zinc is known to have a stabilizing and protective 
effect on bio membranes against oxidative and peroxidative damage (Bettger and O'Dell, 1981). Park et al. (2011) suggested that the positive effects of zinc application under salt stress is included protecting chlorophyll against free radicals, removing the reactive oxygen species, increasing of CAT and PPO activity. In this study, the activities of CAT, PPO and POD enzymes increased by application of zinc. Zinc ions bind to ligands containing sulfur, nitrogen, and to a lesser extent oxygen, and preferentially bind to the membrane proteins (Bettger and O'Dell, 1981). The balance between free radical generation and free radical defense determines the survival of the system. Therefore, $\mathrm{Zn}$ may have a role in modulating free radicals and their related damaging effects by enhancing plants antioxidant systems (Zago and Oteiza, 2001).

Interaction effect between salinity and bio fertilizers showed that the highest activity of CAT and PPO (58.02 and 94.65 OD $\mu \mathrm{g}$ protein $\mathrm{min}^{-1}$ respectively) were obtained in salinity $60 \mathrm{mM}$ with bio fertilizer application as $\mathrm{F}_{3}$ (Fig. 2) and the least activities of them (14.82 and $28.33 \mathrm{OD} \mu \mathrm{g}$ protein $\mathrm{min}^{-1}$ respectively) were obtained in control treatment or $\mathrm{S}_{0} \mathrm{~F}_{0}$ (Fig. 2). On the other hand, there were an increase about $10.5 \%$ and $12.1 \%$ in activity of CAT and PPO enzymes, respectively in the highest salinity level and bio fertilizers $\left(\mathrm{S}_{3} \mathrm{~F}_{3}\right)$ in comparison with $\left(\mathrm{S}_{3} \mathrm{~F}_{0}\right)$ ( Fig. 2).

Also interaction effect between salinity and nano zinc oxide showed that the highest of CAT and PPO activities (57.4 and 94.13 OD $\mu \mathrm{g}$ protein min $^{-1}$ respectively) were obtained in $S_{3} Z_{2}$ (Fig. 2). Also there were an increase about $14.5 \%$ and $9.9 \%$ in activity of CAT and PPO enzymes, respectively in the highest salinity level and nano zinc oxide $\left(\mathrm{S}_{3} \mathrm{Zn}_{2}\right)$ in comparison with $\mathrm{S}_{3} \mathrm{Zn}_{0}$ (Fig. 2).

Plants develop self defense mechanisms by producing antioxidant enzymes like superoxide dismutase, ascorbate peroxidase and catalase (Abdel Latef, 2011). Inoculation with bio fertilizers under salinity stress, significantly increased CAT, POD and PPO enzymes activity. Similar results have been reported by Ma et al. (2011). They suggested that bio fertilizers can improve plant tolerance to salinity and drought and enable plants to survive under unfavourable environmental conditions. Belimov et al. (2009) have reported beneficial effects of bio fertilizers for improving plant growth under normal as well as stressful environment. Similar results have also been reported by Mar Vazquez et al. (2000). Antioxidative enzymes like catalase (CAT), peroxidase (POD) are the most important components in the scavenging system of ROS (Noctor and Foyer, 1998).

\section{Proline content}

Proline has significantly changed during salinity stress and application of bio fertilizers and nano zinc oxide. By increasing the salinity stress, proline content increased. The highest content of proline $\left(9.18,7.78\right.$ and $7.8 \mathrm{mg} \mathrm{g}^{-1} \mathrm{FW}$ respectively) were obtained in the highest of salinity level, application of bio fertilizer as $\mathrm{F}_{3}$ and nano zinc oxide as $\mathrm{Zn}_{2}$ (Fig. 3). The minimum of these values (4.1, 6.41 and $\left.6.59 \mathrm{mg} \mathrm{g}^{-1} \mathrm{FW}\right)$ were obtained in $\mathrm{S}_{0}, \mathrm{~F}_{0}$ and $\mathrm{Zn}_{0}$ respectively (Fig. 3). Also interaction effect between salinity and bio fertilizers showed that the highest of proline $\left(9.72 \mathrm{mg} \mathrm{g}^{-1} \mathrm{FW}\right)$ was obtained in $\mathrm{S}_{3} \mathrm{~F}_{3}$ and the lowest of it $\left(3.82 \mathrm{mgg}^{-1} \mathrm{FW}\right)$ was observed in $\mathrm{S}_{0} \mathrm{~F}_{0}$ (Fig. 4). There was an increase about $16.1 \%$ in content of proline in the highest salinity level and bio fertilizers $\left(\mathrm{S}_{3} \mathrm{~F}_{3}\right)$ in comparison with $\mathrm{S}_{3} \mathrm{~F}_{0}$ (Fig. 4). proline is known to act as an osmo regulator under stress conditions (Ashraf and Foolad, 2007). Proline accumulation in stress condition is a defensive mechanism (Koocheki et al., 2004). So, accumulation of proline in the cell protects the plant by adjusting osmotic pressure as well as by stabilizing many functional units like complex II of the electron transport system, removal of hydroxyl radicals (Mattioli et al., 2009). Proline reduces cytoplasmic $\mathrm{pH}$ and maintains the proper ratio of $\mathrm{NADP}^{+} / \mathrm{NADPH}$ in metabolism and increase different enzymes activities (Szabados and Savoure, 2009). Some studies demonstrated that AM association affects the physiological processes of plants by increasing proline contents (Ruiz-Lozano $e t$ al., 1995). Proline accumulation was studied in resistant and nonresistant varieties of Silen vulgaris to increasing concentrations of zinc (Schat et al., 1997).

\section{Soluble sugars}

The results of measurement of soluble sugars showed the concentration of soluble sugars increased under salinity stress. The highest content of soluble sugars $\left(99.48 \mathrm{mg} \mathrm{g}^{-1} \mathrm{FW}\right)$ was obtained in $60 \mathrm{mM}$, application bio fertilizers as $\mathrm{F}_{3}$ nano zinc oxide as $\mathrm{Zn}_{2}$ Also the minimum of it $\left(25.11 \mathrm{mg} \mathrm{g}^{-1} \mathrm{FW}\right)$ was observed in
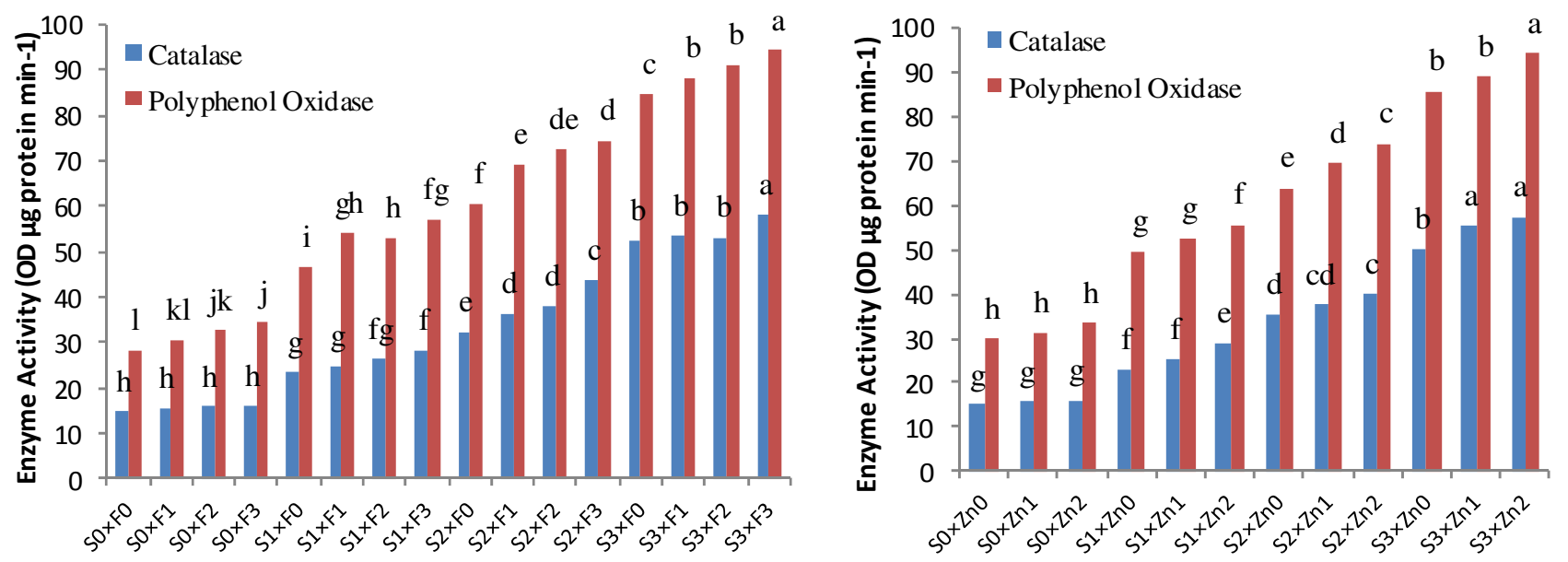

Fig. 2. Effect of salinity and bio fertilizers application, salinity and nano zinc oxide on CAT and PPO activity of triticale; $S_{0}, S_{1}, S_{2}$ and $S_{3}$ are nosalt (control), salinity 20, 40 and $60 \mathrm{mM} \mathrm{NaCl}$ ), respectively. $F_{0}, F_{1}, F_{2}$ and $F_{3}$ are no bio fertilizer, application of mycorrhiza, PGPR, both applications PGPR and mycorrhiza respectively. $\mathrm{Zn}_{0}, \mathrm{Zn}_{1}$ and $\mathrm{Zn}_{2}$ are without nano zinc oxide as control, application of 0.4 and $0.8 \mathrm{~g}$ lit ${ }^{-1}$ respectively 
120
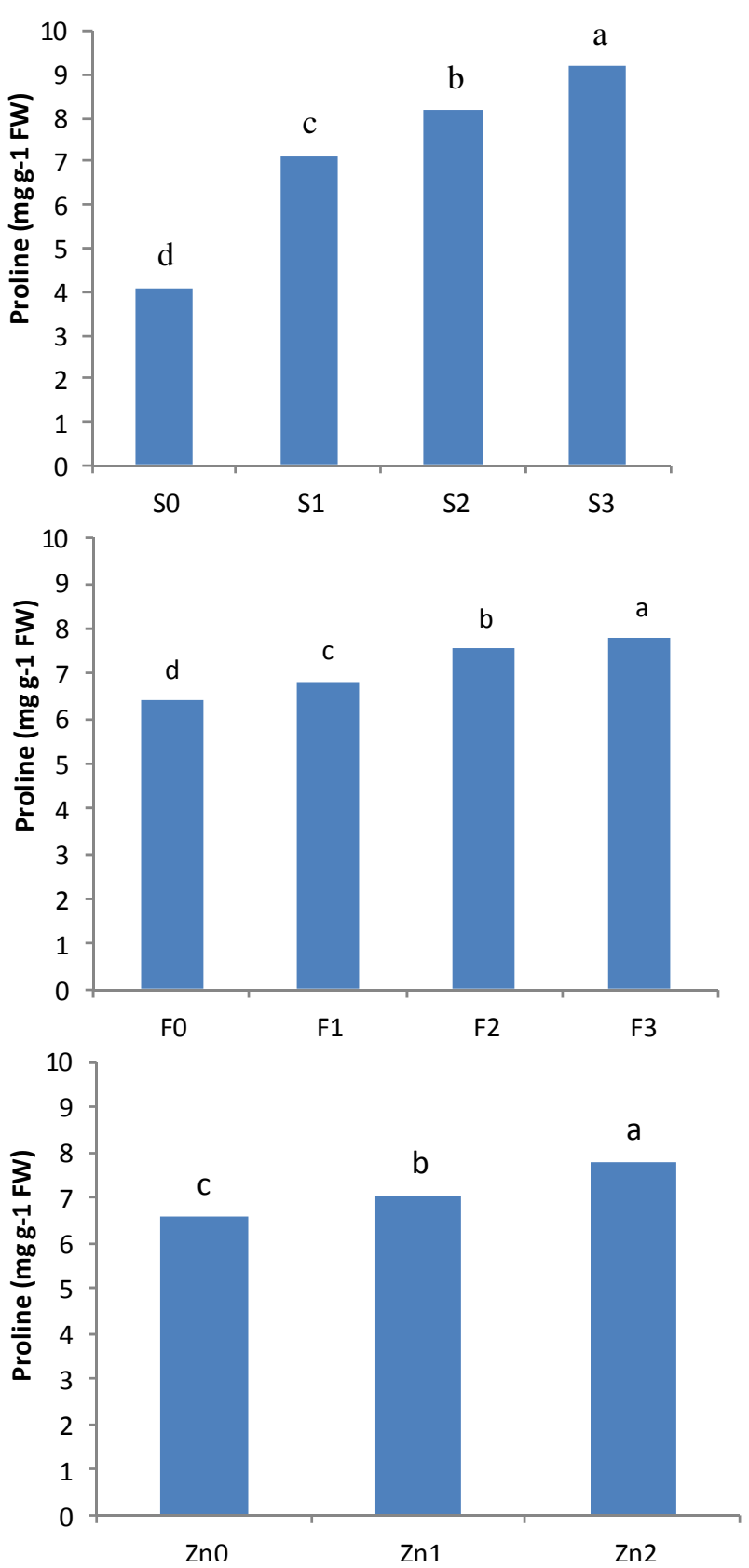

Fig. 3. Effect of salinity, bio fertilizers and nano zinc oxide on proline content of triticale; $S_{0}, S_{1}, S_{2}$ and $S_{3}$ are no-salt (control), salinity 20,40 and $60 \mathrm{mM} \mathrm{NaCl}$ ), respectively. $F_{0}, F_{1}, F_{2}$ and $F_{3}$ are no bio fertilizer, application of mycorrhiza, PGPR, both applications PGPR and mycorrhiza respectively. $\mathrm{Zn}_{0}, \mathrm{Zn}_{1}$ and $\mathrm{Zn}_{2}$ are without nano zinc oxide as control, application of 0.4 and 0.8 glit $^{-1}$ respectively

control treatment $\left(\mathrm{S}_{0}, \mathrm{~F}_{0}\right.$ and $\left.\mathrm{Zn}_{0}\right)$ (Table 1). Results showed that at the highest salinity level, application bio fertilizers as $\mathrm{F}_{3}$ and nano zinc oxide as $\mathrm{Zn}_{2}$ increase about $72.3 \%$ in content of soluble sugars in comparison with $\mathrm{F}_{0}$ and $\mathrm{Zn}_{0}$ in the same salinity level (Table 1). Van and Clijsters (1990) indicated that salinity increased soluble sugars. Accumulation of soluble sugars helps regulate osmotic in plant cells and leads to preservation of biological molecules and membranes and maintaining turgor pressure via osmotic regulation (Irannejad and Shahbazian, 2004). Concentration of sugars may increase photosynthesis of plants during stress and also prevent plasmolysis (Sato et al., 2004). In a saline environment

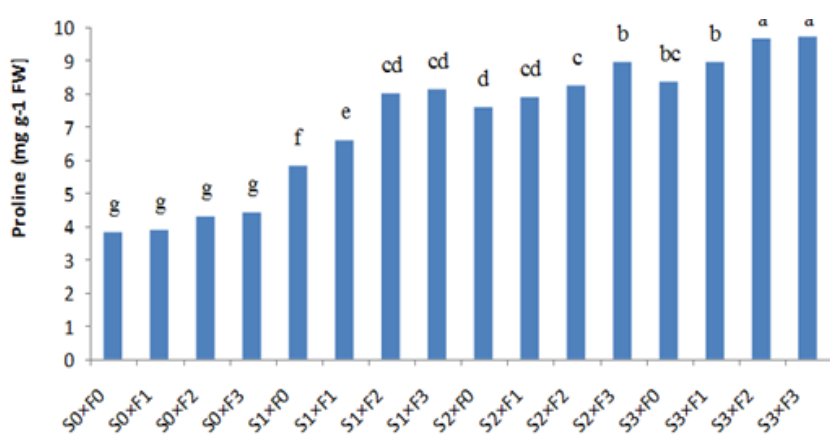

Fig. 4. Effect of salinity and bio fertilizers application on proline content of triticale; $S_{0}, S_{1}, S_{2}$ and $S_{3}$ are no-salt (control), salinity 20,40 and $60 \mathrm{mM} \mathrm{NaCl}$ ), respectively. $F_{0}, F_{1}, F_{2}$ and $F_{3}$ are no bio fertilizer, application of mycorrhiza, PGPR, both applications PGPR and mycorrhiza respectively

plant water uptake decreases due to changes in soil water potential. Under such conditions, accumulation of compatible solutes like soluble sugars, proline, glycine betaine and many other such organic solutes, takes place in the plant body that plays an important role to protect the plant from the stress induced deleterious effects by osmotic adjustment, limiting water loss and diluting the concentration of toxic ions (Slama et al., 2006). The plant with the increase in soluble sugar and maintaining the osmotic potential in stress conditions, will be able to store their carbohydrate metabolism of the cell is kept at an optimum level (Gibson, 2005). It was stated of VAM fungi significantly increasing photosynthetic of host plants and there by causing an increase in sugar content (Marschner and Dell, 1994).

\section{Photosyntheticpigments}

Salinity stress, bio fertilizers and nano zinc oxide application significantly affected the photosynthetic pigment content. The highest content of chlorophyll $a\left(6.61 \mathrm{mg} \mathrm{g}^{-1} \mathrm{FW}\right)$, chlorophyll $b$ (1.84 $\left.\mathrm{mg} \mathrm{g}^{-1} \mathrm{FW}\right)$, total chlorophyll $\left(8.45 \mathrm{mg} \mathrm{g}^{-1} \mathrm{FW}\right)$ and Carotenoid $\left(0.88 \mathrm{mgg}^{-1} \mathrm{FW}\right)$ were obtained in $\mathrm{S}_{0} \mathrm{~F}_{3} \mathrm{Zn}_{2}$, while the lowest values (1.74 $\mathrm{mg} \mathrm{g}^{-1} \mathrm{FW}, 0.58 \mathrm{mg} \mathrm{g}^{-1} \mathrm{FW}, 2.32 \mathrm{mg} \mathrm{g}^{-1} \mathrm{FW}$ and $0.173 \mathrm{mg} \mathrm{g}^{-1} \mathrm{FW}$ respectively) were determined in $\mathrm{S}_{3} \mathrm{~F}_{0} \mathrm{Zn}_{0}$ (Tables 2 and 3). Results showed that in the highest salinity level, application bio fertilizers as $\mathrm{F}_{3}$ and nano zinc oxide as $\mathrm{Zn}_{2}$ increased about $69.5 \%, 81 \%, 72.8 \%$ and $64.7 \%$ content of chlorophyll $a$, chlorophyll $b$, total chlorophyll and Carotenoid respectively, in comparison with $\mathrm{F}_{0}$ and $\mathrm{Zn}_{0}$ (Tables 2 and 3 ).

Salinity stress caused the reduction in chlorophyll content while the application of bio fertilizers and nano zinc oxide enhanced the chlorophyll content, which revealed the bio fertilizers and nano zinc oxide important in mitigating stress effect. Environmental stress reduced chlorophyll and carotenoids content. The main reason for the decrease in chlorophyll may be degradation by reactive oxygen species (ROS). Another reason for the decline in chlorophyll is the application of a glutamate precursor for the biosynthesis of proline (Navari-Izzo et al., 1990). Sultana et al. (1999) reported that decrease in carotenoids in salt stress is Beta carotene destruction and Zea xanthin formation. It was reported that total chlorophyll and carotenoids are decreased in tomato under salt stress (Parida and Das, 2005). Reduction of chlorophyll and other pigments finally resulted in decrease in the efficiency of photosynthesis (Basra and Basra, 1997). Giri et al. (2003) found that mixed inoculation of six arbuscular mycorrhizal fungi species enhanced the chlorophyll content in Acacia auriculiformis under salinity stress. Sannazzora etal.(2005) 
Table 1. Interaction effect between salinity $\times$ biofertilizers $\times$ nano zinc oxide on soluble sugars of triticale

\begin{tabular}{|c|c|c|c|c|}
\hline \multicolumn{2}{|c|}{ Treatment } & \multicolumn{3}{|c|}{$\begin{array}{c}\text { Soluble Sugars }\left(\mathrm{mg} \mathrm{g}^{-1} \mathrm{FW}\right) \\
\text { Zinc levels }\left(\mathrm{g}_{\text {lit }}{ }^{-1}\right)\end{array}$} \\
\hline \multirow{2}{*}{ Salinity Stress } & \multirow{2}{*}{ Bio Fertilizers } & \multicolumn{3}{|c|}{ Zinc levels $\left(\mathrm{g}\right.$ lit $\left.^{-1}\right)$} \\
\hline & & 0 & 0.4 & 0.8 \\
\hline & $\mathrm{F}_{0}$ & $25.11 \pm 5.61$ & $32.01 \pm 4.83$ & $35.17 \pm 5.65$ \\
\hline \multirow[t]{4}{*}{$S_{0}$} & $F_{1}$ & $27.08 \pm 5.70$ & $37.12 \pm 7.46$ & $37.03 \pm 8.23$ \\
\hline & $\mathrm{F}_{2}$ & $34.29 \pm 4.27$ & $38.68 \pm 7.19$ & $40.37 \pm 6.78$ \\
\hline & $\mathrm{F}_{3}$ & $39.67 \pm 6.94$ & $40.55 \pm 7.36$ & $41.52 \pm 6.41$ \\
\hline & $\mathrm{F}_{0}$ & $42.58 \pm 5.66$ & $43.98 \pm 4.87$ & $45.75 \pm 3.43$ \\
\hline \multirow[t]{4}{*}{$S_{1}$} & $\mathrm{~F}_{1}$ & $40.47 \pm 0.77$ & $46.59 \pm 4.84$ & $50.67 \pm 8.04$ \\
\hline & $\mathrm{F}_{2}$ & $45.24 \pm 2.80$ & $51.18 \pm 8.20$ & $58.28 \pm 5.47$ \\
\hline & $\mathrm{F}_{3}$ & $51.98 \pm 2.84$ & $55.97 \pm 6.01$ & $63.01 \pm 5.10$ \\
\hline & $\mathrm{F}_{0}$ & $48.54 \pm 3.70$ & $48.67 \pm 4.73$ & $51.85 \pm 7.15$ \\
\hline \multirow[t]{4}{*}{$S_{2}$} & $\mathrm{~F}_{1}$ & $57.60 \pm 4.52$ & $69.36 \pm 5.42$ & $78.61 \pm 7.60$ \\
\hline & $\mathrm{F}_{2}$ & $56.06 \pm 2.49$ & $63.47 \pm 3.04$ & $61.44 \pm 6.90$ \\
\hline & $\mathrm{F}_{3}$ & $62.01 \pm 2.34$ & $73.93 \pm 4.64$ & $81.79 \pm 1.73$ \\
\hline & $\mathrm{F}_{0}$ & $57.72 \pm 1.44$ & $62.43 \pm 2.68$ & $66.44 \pm 5.37$ \\
\hline \multirow[t]{4}{*}{$S_{3}$} & $F_{1}$ & $65.75 \pm 3.23$ & $71.28 \pm 3.09$ & $94.29 \pm 3.10$ \\
\hline & $\mathrm{F}_{2}$ & $83.68 \pm 4.53$ & $89.97 \pm 5.63$ & $93.82 \pm 4.92$ \\
\hline & $\mathrm{F}_{3}$ & $87.59 \pm 3.48$ & $97.18 \pm 1.17$ & $99.48 \pm 1.44$ \\
\hline & & & 4.42 & \\
\hline
\end{tabular}

Difference between mean difference treatments significant differences (LSD test, $\mathrm{P}<0.05$ ); $\mathrm{S}_{0}, \mathrm{~S}_{1}, \mathrm{~S}_{2}$ and $\mathrm{S}_{3}$ are no-salt (control), salinity 20,40 and $60 \mathrm{mM} \mathrm{NaCl}$ ), respectively. $\mathrm{F}_{0}, \mathrm{~F}_{1}, \mathrm{~F}_{2}$ and $\mathrm{F}_{3}$ are no bio fertilizer, application of mycorrhiza, PGPR, both applications PGPR and mycorrhiza respectively.

Table 2. Interaction effect between salinity $\times$ biofertilizers $\times$ nano zinc oxide on chlorophyll $a$ and chlorophyll $b$ of triticale

\begin{tabular}{|c|c|c|c|c|c|c|c|}
\hline \multicolumn{2}{|c|}{ Treatment } & \multirow{2}{*}{\multicolumn{3}{|c|}{$\begin{array}{c}\text { Chlorophyll } a\left(\mathrm{mg} \mathrm{g}^{-1} \mathrm{FW}\right) \\
\text { Zinc levels }\left(\mathrm{g} \mathrm{lit}^{-1}\right) \\
\end{array}$}} & \multirow{2}{*}{\multicolumn{3}{|c|}{$\begin{array}{c}\text { Chlorophyll } b\left(\mathrm{mg} \mathrm{g}^{-1} \mathrm{FW}\right) \\
\text { Zinc levels }\left(\mathrm{g} \mathrm{lit}^{-1}\right) \\
\end{array}$}} \\
\hline \multirow{2}{*}{ Salinity Stress } & \multirow{2}{*}{ Bio Fertilizers } & & & & & & \\
\hline & & 0 & 0.4 & 0.8 & 0 & 0.4 & 0.8 \\
\hline & $\mathrm{F}_{0}$ & $4.05 \pm 0.20$ & $4.20 \pm 0.17$ & $4.20 \pm 0.40$ & $1.20 \pm 0.30$ & $1.31 \pm 0.29$ & $1.37 \pm 0.25$ \\
\hline \multirow[t]{4}{*}{$S_{0}$} & $\mathrm{~F}_{1}$ & $4.10 \pm 0.35$ & $4.34 \pm 0.16$ & $5.11 \pm 0.46$ & $1.34 \pm 0.25$ & $1.53 \pm 0.35$ & $1.65 \pm 0.29$ \\
\hline & $\mathrm{F}_{2}$ & $4.35 \pm 0.04$ & $5.35 \pm 0.41$ & $6.22 \pm 0.51$ & $1.33 \pm 0.29$ & $1.46 \pm 0.33$ & $1.73 \pm 0.36$ \\
\hline & $\mathrm{F}_{3}$ & $4.50 \pm 0.39$ & $5.84 \pm 0.39$ & $6.61 \pm 0.40$ & $1.46 \pm 0.21$ & $1.44 \pm 0.28$ & $1.84 \pm 0.28$ \\
\hline & $\mathrm{F}_{0}$ & $3.34 \pm 0.26$ & $3.60 \pm 0.09$ & $3.84 \pm 0.08$ & $0.86 \pm 0.33$ & $0.89 \pm 0.37$ & $0.92 \pm 0.36$ \\
\hline \multirow[t]{4}{*}{$S_{1}$} & $\mathrm{~F}_{1}$ & $3.39 \pm 0.17$ & $3.65 \pm 0.08$ & $3.73 \pm 0.56$ & $0.97 \pm 0.36$ & $1.16 \pm 0.37$ & $1.19 \pm 0.28$ \\
\hline & $\mathrm{F}_{2}$ & $3.56 \pm 0.43$ & $3.64 \pm 0.42$ & $4.31 \pm 0.43$ & $1.09 \pm 0.34$ & $1.29 \pm 0.32$ & $1.33 \pm 0.32$ \\
\hline & $\mathrm{F}_{3}$ & $3.56 \pm 0.32$ & $4.28 \pm 0.36$ & $4.45 \pm 0.34$ & $1.20 \pm 0.31$ & $1.41 \pm 0.33$ & $1.47 \pm 0.26$ \\
\hline & $\mathrm{F}_{0}$ & $2.18 \pm 0.38$ & $2.22 \pm 0.31$ & $2.64 \pm 0.40$ & $0.77 \pm 0.27$ & $0.92 \pm 0.31$ & $0.95 \pm 0.32$ \\
\hline \multirow[t]{4}{*}{$S_{2}$} & $F_{1}$ & $2.24 \pm 0.36$ & $2.86 \pm 0.35$ & $3.41 \pm 0.47$ & $0.78 \pm 0.31$ & $0.78 \pm 0.35$ & $0.9 \pm 0.34$ \\
\hline & $\mathrm{F}_{2}$ & $2.81 \pm 0.36$ & $3.21 \pm 0.40$ & $3.57 \pm 0.50$ & $0.69 \pm 0.32$ & $0.77 \pm 0.33$ & $1.04 \pm 0.38$ \\
\hline & $\mathrm{F}_{3}$ & $2.82 \pm 0.36$ & $3.38 \pm 0.37$ & $3.61 \pm 0.23$ & $0.97 \pm 0.35$ & $1.23 \pm 0.31$ & $1.25 \pm 0.33$ \\
\hline & $\mathrm{F}_{0}$ & $1.74 \pm 0.36$ & $2.05 \pm 0.36$ & $2.28 \pm 0.36$ & $0.58 \pm 0.31$ & $0.73 \pm 0.32$ & $0.8 \pm 0.33$ \\
\hline \multirow[t]{3}{*}{$S_{3}$} & $F_{1}$ & $1.93 \pm 0.37$ & $2.16 \pm 0.34$ & $2.36 \pm 0.35$ & $0.64 \pm 0.30$ & $0.73 \pm 0.34$ & $0.86 \pm 0.32$ \\
\hline & $F_{2}$ & $1.95 \pm 0.31$ & $2.10 \pm 0.35$ & $2.53 \pm 0.33$ & $0.62 \pm 0.32$ & $0.82 \pm 0.32$ & $0.88 \pm 0.33$ \\
\hline & $\mathrm{F}_{3}$ & $2.04 \pm 0.32$ & $2.17 \pm 0.36$ & $2.95 \pm 0.34$ & $0.68 \pm 0.32$ & $0.92 \pm 0.34$ & $1.05 \pm 0.34$ \\
\hline \multicolumn{2}{|c|}{$\mathrm{LSD}_{0.05}$} & & 0.23 & & & 0.09 & \\
\hline
\end{tabular}

Difference between mean difference treatments significant differences (LSD test, $\mathrm{P}<0.05$ );

$\mathrm{S}_{0}, \mathrm{~S}_{1}, \mathrm{~S}_{2}$ and $\mathrm{S}_{3}$ are no-salt (control), salinity 20,40 and $60 \mathrm{mM} \mathrm{NaCl}$ ), respectively. $\mathrm{F}_{0}, \mathrm{~F}_{1}, \mathrm{~F}_{2}$ and $\mathrm{F}_{3}$ are no bio fertilizer, application of mycorrhiza, PGPR, both applications PGPR and mycorrhiza respectively.

reported plants inoculated with Glomus intraradices had higher protein and chlorophyll density in comparison with nonmycorrhiza inoculated plants. In thisstudy, photosynthetic pigments were increased under the effect of co-inoculation with PGPR and mycorrhizal. Giri and Mukerji (2004) reported that mycorrhiza and PGPR decrease effects of salinity in chlorophyll synthesis. Shaharoona et al. (2006) reported that inoculation with PGPR containing ACC-deaminase activity significantly affected the pigments under salinity stress. Sharma et al. (1994) reported that added zinc enhanced the growth of cabbage and improved the chlorophyll content and photosynthetic activity in the leaves.
Zarrouk et al. (2005) indicated a positive correlation of $\mathrm{Zn}$ concentrations with leaf chlorophyll content in plants.

\section{Grain yield}

The salinity stress, bio fertilizers and nano zinc oxide foliar significantly affected the grain yield per plant. The highest grain yield (3.64 g per plant) was obtained in no-salinity, application of bio fertilizer as $\mathrm{F}_{3}$ and nano zinc oxide as $\mathrm{Zn}_{2}$ (Table 4). The lowest grain yield per plant $(1.65 \mathrm{~g})$ was determined in the highest salinity level and without application of bio fertilizers and nano zinc oxide (Table 4). Azcón and Barea (2010) has been proposed co- 
122

Table 3. Interaction effect between salinity $\times$ biofertilizers $\times$ nano zinc oxide on total chlorophyll and carotenoid of triticale

\begin{tabular}{|c|c|c|c|c|c|c|c|}
\hline \multicolumn{2}{|c|}{ Treatment } & \multirow{2}{*}{\multicolumn{3}{|c|}{$\begin{array}{c}\text { Total Chlorophyll }\left(\mathrm{mg} \mathrm{g}^{-1} \mathrm{FW}\right) \\
\text { Zinc levels }\left(\mathrm{g} \mathrm{lit}^{-1}\right) \\
\end{array}$}} & \multirow{2}{*}{\multicolumn{3}{|c|}{$\begin{array}{c}\text { Carotenoid }\left(\mathrm{mg} \mathrm{g}^{-1} \mathrm{FW}\right) \\
\text { Zinc levels }\left(\mathrm{g} \mathrm{lit}^{-1}\right) \\
\end{array}$}} \\
\hline \multirow{2}{*}{ Salinity Stress } & \multirow{2}{*}{ Bio Fertilizers } & & & & & & \\
\hline & & 0 & 0.4 & 0.8 & 0 & 0.4 & 0.8 \\
\hline & $\mathrm{F}_{0}$ & $5.26 \pm 0.48$ & $5.52 \pm 0.45$ & $5.57 \pm 0.65$ & $0.526 \pm 0.008$ & $0.549 \pm 0.008$ & $0.593 \pm 0.041$ \\
\hline \multirow[t]{4}{*}{$S_{0}$} & $\mathrm{~F}_{1}$ & $5.45 \pm 0.61$ & $5.88 \pm 0.44$ & $6.77 \pm 0.76$ & $0.543 \pm 0.009$ & $0.544 \pm 0.005$ & $0.542 \pm 0.047$ \\
\hline & $\mathrm{F}_{2}$ & $5.69 \pm 0.32$ & $6.82 \pm 0.70$ & $7.96 \pm 0.82$ & $0.530 \pm 0.007$ & $0.593 \pm 0.071$ & $0.763 \pm 0.076$ \\
\hline & $\mathrm{F}_{3}$ & $5.96 \pm 0.58$ & $7.29 \pm 0.65$ & $8.45 \pm 0.67$ & $0.559 \pm 0.045$ & $0.751 \pm 0.044$ & $0.880 \pm 0.036$ \\
\hline & $\mathrm{F}_{0}$ & $4.21 \pm 0.57$ & $4.50 \pm 0.44$ & $4.77 \pm 0.43$ & $0.328 \pm 0.066$ & $0.403 \pm 0.062$ & $0.446 \pm 0.044$ \\
\hline \multirow[t]{4}{*}{$S_{1}$} & $\mathrm{~F}_{1}$ & $4.36 \pm 0.51$ & $4.81 \pm 0.44$ & $4.92 \pm 0.81$ & $0.403 \pm 0.035$ & $0.408 \pm 0.045$ & $0.435 \pm 0.043$ \\
\hline & $\mathrm{F}_{2}$ & $4.66 \pm 0.73$ & $4.94 \pm 0.75$ & $5.65 \pm 0.76$ & $0.404 \pm 0.083$ & $0.439 \pm 0.034$ & $0.434 \pm 0.046$ \\
\hline & $\mathrm{F}_{3}$ & $4.76 \pm 0.64$ & $5.70 \pm 0.70$ & $5.93 \pm 0.60$ & $0.418 \pm 0.056$ & $0.456 \pm 0.031$ & $0.475 \pm 0.015$ \\
\hline & $\mathrm{F}_{0}$ & $2.95 \pm 0.62$ & $3.14 \pm 0.60$ & $3.59 \pm 0.72$ & $0.252 \pm 0.060$ & $0.326 \pm 0.080$ & $0.353 \pm 0.028$ \\
\hline \multirow[t]{4}{*}{$S_{2}$} & $\mathrm{~F}_{1}$ & $2.96 \pm 0.55$ & $3.65 \pm 0.69$ & $4.31 \pm 0.79$ & $0.389 \pm 0.002$ & $0.382 \pm 0.073$ & $0.388 \pm 0.034$ \\
\hline & $\mathrm{F}_{2}$ & $3.51 \pm 0.66$ & $3.99 \pm 0.73$ & $4.61 \pm 0.89$ & $0.352 \pm 0.075$ & $0.393 \pm 0.072$ & $0.401 \pm 0.066$ \\
\hline & $\mathrm{F}_{3}$ & $3.8 \pm 0.68$ & $4.61 \pm 0.68$ & $4.86 \pm 0.55$ & $0.346 \pm 0.075$ & $0.371 \pm 0.033$ & $0.410 \pm 0.036$ \\
\hline & $\mathrm{F}_{0}$ & $2.32 \pm 0.66$ & $2.79 \pm 0.67$ & $3.09 \pm 0.68$ & $0.173 \pm 0.055$ & $0.182 \pm 0.051$ & $0.215 \pm 0.075$ \\
\hline \multirow[t]{3}{*}{$S_{3}$} & $\mathrm{~F}_{1}$ & $2.57 \pm 0.65$ & $2.89 \pm 0.66$ & $3.23 \pm 0.67$ & $0.178 \pm 0.058$ & $0.235 \pm 0.083$ & $0.257 \pm 0.061$ \\
\hline & $\mathrm{F}_{2}$ & $2.58 \pm 0.62$ & $2.92 \pm 0.67$ & $3.41 \pm 0.67$ & $0.262 \pm 0.060$ & $0.226 \pm 0.094$ & $0.272 \pm 0.069$ \\
\hline & $\mathrm{F}_{3}$ & $2.73 \pm 0.62$ & $3.10 \pm 0.68$ & $4.01 \pm 0.67$ & $0.253 \pm 0.071$ & $0.255 \pm 0.061$ & $0.285 \pm 0.038$ \\
\hline \multicolumn{2}{|c|}{$\mathrm{LSD}_{0.05}$} & & 0.05 & & & 0.075 & \\
\hline
\end{tabular}

Difference between mean difference treatments significant differences (LSD test, $\mathrm{P}<0.05$ );

$S_{0}, S_{1}, S_{2}$ and $S_{3}$ are no-salt (control), salinity 20,40 and $60 \mathrm{mM} \mathrm{NaCl}$ ), respectively. $F_{0}, F_{1}, F_{2}$ and $F_{3}$ are no bio fertilizer, application of mycorrhiza, PGPR, both applications PGPR and mycorrhiza respectively

Table 4. Interaction effect between salinity $\times$ biofertilizers $\times$ nano zinc oxide on yield of triticale

\begin{tabular}{|c|c|c|c|c|}
\hline \multicolumn{2}{|c|}{ Treatment } & \multirow{2}{*}{\multicolumn{3}{|c|}{$\begin{array}{l}\text { Yield (g per plant) } \\
\text { Zinc levels }\left(\mathrm{g} \mathrm{lit}^{-1}\right)\end{array}$}} \\
\hline \multirow{2}{*}{ Salinity Stress } & \multirow{2}{*}{ Bio Fertilizers } & & & \\
\hline & & 0 & 0.4 & 0.8 \\
\hline & $\mathrm{F}_{0}$ & $2.45 \pm 0.1$ & $2.68 \pm 0.06$ & $2.82 \pm 0.09$ \\
\hline \multirow[t]{4}{*}{$S_{0}$} & $\mathrm{~F}_{1}$ & $2.72 \pm 0.09$ & $2.89 \pm 0.08$ & $3.10 \pm 0.06$ \\
\hline & $\mathrm{F}_{2}$ & $3.10 \pm 0.01$ & $3.10 \pm 0.10$ & $3.39 \pm 0.06$ \\
\hline & $\mathrm{F}_{3}$ & $3.11 \pm 0.09$ & $3.41 \pm 0.07$ & $3.64 \pm 0.05$ \\
\hline & $\mathrm{F}_{0}$ & $2.34 \pm 0.05$ & $2.43 \pm 0.08$ & $2.6 \pm 0.09$ \\
\hline \multirow[t]{4}{*}{$S_{1}$} & $F_{1}$ & $2.49 \pm 0.01$ & $2.6 \pm 0.09$ & $2.86 \pm 0.07$ \\
\hline & $F_{2}$ & $2.72 \pm 0.10$ & $2.93 \pm 0.09$ & $3.00 \pm 0.10$ \\
\hline & $\mathrm{F}_{3}$ & $2.91 \pm 0.06$ & $3.01 \pm 0.06$ & $3.28 \pm 0.13$ \\
\hline & $\mathrm{F}_{0}$ & $1.93 \pm 0.10$ & $2.12 \pm 0.09$ & $2.32 \pm 0.10$ \\
\hline \multirow[t]{4}{*}{$S_{2}$} & $F_{1}$ & $2.06 \pm 0.08$ & $2.20 \pm 0.10$ & $2.43 \pm 0.08$ \\
\hline & $\mathrm{F}_{2}$ & $2.21 \pm 0.08$ & $2.32 \pm 0.11$ & $2.54 \pm 0.08$ \\
\hline & $\mathrm{F}_{3}$ & $2.52 \pm 0.10$ & $2.73 \pm 0.13$ & $2.89 \pm 0.09$ \\
\hline & $\mathrm{F}_{0}$ & $1.65 \pm 0.07$ & $1.82 \pm 0.09$ & $2.08 \pm 0.10$ \\
\hline \multirow[t]{3}{*}{$S_{3}$} & $F_{1}$ & $1.82 \pm 0.11$ & $1.96 \pm 0.11$ & $2.12 \pm 0.11$ \\
\hline & $F_{2}$ & $1.94 \pm 0.13$ & $2.20 \pm 0.10$ & $2.33 \pm 0.11$ \\
\hline & $\mathrm{F}_{3}$ & $2.13 \pm 0.11$ & $2.23 \pm 0.12$ & $2.31 \pm 0.09$ \\
\hline \multicolumn{2}{|c|}{$\mathrm{LSD}_{0.05}$} & & 0.04 & \\
\hline
\end{tabular}

Difference between mean difference treatments significant differences (LSD test, $\mathrm{P}<0.05$ ); $\mathrm{S}_{0}, \mathrm{~S}_{1}, \mathrm{~S}_{2}$ and $\mathrm{S}_{3}$ are no-salt (control), salinity 20,40 and $60 \mathrm{mM} \mathrm{NaCl}$ ), respectively. $\mathrm{F}_{0}, \mathrm{~F}_{1}, \mathrm{~F}_{2}$ and $\mathrm{F}_{3}$ are no bio fertilizer, application of mycorrhiza, PGPR, both applications PGPR and mycorrhiza respectively.

inoculation with bio fertilizer as an efficient procedure to increase plant growth. Vivas et al. (2003) suggested that there are synergistic effects on plant growth when PGPR and mycorrhiza are inoculated, particularly under growth limited conditions.

\section{Conclusion}

The results showed that salinity stress reduced grain yield per plant and chlorophyll content of the plants. But antioxidant enzymes activity, soluble sugars and proline increased. Also application of bio fertilizer and nano zinc oxide improved of grain yield, chlorophyll content, antioxidant enzyme activity, proline and soluble sugars under salinity condition. Our results suggested that plants apply defensive mechanisms, such as syntheses of antioxidant enzymes, soluble sugars and proline to improvement effects of stress. It seems that application of bio fertilizer and nano zinc oxide can be recommended for profitable triticale production under salinity condition.

\section{References}

Abdel Latef AA (2011). Influence of arbuscular mycorrhizal fungi and copper on growth, accumulation of osmolyte, mineral nutrition and antioxidant enzyme activity of pepper (Capsicum aпnиum L.). 
Mycorrhiza21:495-503.

Arnon DI (1949). Copper enzymes in isolated chloroplast polyphenol oxidase in Beta vulgaris. Plant Physiology 24(1):1-15.

Arzanesh MH, Alikhani HA, Khavazi K, Rahimian HA, Miransari M (2009). In vitro growth of wheat (Triticum aestivum L.) seedlings, inoculated with Azospirillum sp., under drought stress. International Journal of Botany 5:244249.

Ashraf M, Foolad MR (2007). Roles of gycine betaine and proline in improving plant abiotic stress resistance. Environmental and Experimental Botany 59:206-216.

Azcon R, Barea JM (2010). Mycorrhizosphere interactions for legume improvement. In: Khanf MS, Zaidi A, Musarrat J (Eds). Microbes for legume improvement. Vienna, Springer pp 237-271.

Basra AS, Basra RK (1997). Mechanism of Environmental Stress Resistance in Plants. Amsterdam, Harwood Academic Publishers.

Bates L, Waldren SRP, Teare ID (1973). Rapid determination of free proline for water stress studies. Plant and Soil 39:205-207.

Belimov AA, Dodd IC, Safronova VI, Davies WJ (2009). ACC deaminase containing rhizobacteria improve vegetative development and yield of potato plants grown under water limited conditions. Aspects of Applied Biology 98:163-169.

Bettger WJ, O'Dell BL (1981). A critical physiological role of zinc in the structure and function of biomembranes. Life Sciences 28:1425-1438.

Bianco C, Imperlini E, Defez R (2009). Legume like more IAA. Plant Signaling and Behavior 4:763-765.

Bradford MM (1976). A rapid and sensitive for the quantitation of microgram quantities of protein utilizing the principle of protein-dye binding. Analytical Biochemistry 72:248-254.

BurkeJJ, Mahan JR (1991). Environmental regulation of cellular protection systems. In Gausman HW (Ed). Plant Biochemical Regulators. New York, MarcelDekkerIncpp 47-58.

Cakmak I (2008). Enrichment of cereal grains with zinc: Agronomic or genetic biofortification? Plant and Soil 302:1-17.

Cantale C, Petrazzuolo F, Correnti A, Farneti A, Felici F, Latini A, Galeffi P (2016). Triticale for Bioenergy Production. Agriculture and Agricultural Science Procedia 8:609-616.

Dimkpa C, Weinand T, Ash F (2009). Plant-rhizobacteria interactions alleviate abiotic stress conditions. Plant, Cell and Environment 32:16821694.

Dubois M, Gilles KA, Hamilton IK, Rcbers PA, Smith F (1956). Colorimetric method for determination of sugars and related substances. Analytical Chemistry 28:350-356.

Ebrahimian E, Bybordi A (2011). Exogenous silicium and zinc increase antioxidant enzyme activity and all eviate salt stress in leaves of sunflower. Journal of Food, Agriculture and Environment 9(1):422-427.

Evelin H, Giri B, Kapoor R (2013). Ultrastructural evidence for AMF mediated salt stress mitigation in Trigonella foenum-gr aecum. Mycorrhiza23:71-86.

Fageria NK, Baligar VC, Clark RB (2002). Micronutrients in crop production. Advances in Agronomy 77:189-272.

Foyer CH, Shigeoka S (2011). Understanding oxidative stress and antioxidant functions in order to enhance photosynthesis. Plant Physiology 155:93-100.
Gamalero E, Berta G, Glick BR (2009). The use of microorganisms to facilitate the growth of plants in saline soils. In: Khan MS, Zaidi A, Musarrat J (Eds). Microbial strategies for crop improvement. Dordrecht Heidelberg, London, Springer pp 1-22.

Gibson S (2005). Control of plant development and gene expression by sugar signaling.Journal of Plant Biology 8(1):93-102.

Gill SS, Tuteja N (2010). Reactive oxygen species and antioxidant machinery in abiotic stress tolerance in crop plants. Plant Physiology and Biochemistry 48:909-930.

Giri B, Kapoor R, Mukerji KG (2003). Influence of arbuscular mycorrhizal fungi and salinity on growth, biomass, and mineral nutrition of Acacia auriculiformis. Biology and Fertility of Soils 38:170-175.

Giri B, Mukerji KG (2004). Mycorrhizal inoculants alleviates salt stress in Sesbania aegyptiaca and Sesbania grandiflora under field conditions: evidence for reduced sodium and improved magnesium uptake. Mycorrhiza 14:307-312.

Hmaeid N, Metoui O, Wali M,Zorrig W, Abdelly C (2014). Comparative effects of Rhizobacteria in promoting growth of Hordeum maritimum L. plants under salt stress. Journal of Plant Biology Research 3(1):37-50.

Irannejad H, Shahbazian N (2004). Field crops tolerance to stress. University of Tehran Press.

Jin X, Huang Y,ZengF,Zhou M,ZhangG (2009). Genotypic difference in response of peroxidase and superoxide dismutase isozymes and activities to salt stress in barley. Acta Physiologiae Plantarum 31:1103-1109.

Kapoor R, Evelin H, Mathur P, Giri B (2013). Arbuscular mycorrhiza: Approaches for abiotic stress tolerance in crop plants for sustainable agriculture. In: Tuteja N, Gill SS (Eds). Plant acclimation to environmental stress. Springer LLC pp 359-401.

Karo M, Mishra D (1976). Catalase, peroxidase and polyphenol oxidase activity during riceleaf senescence. Plant Physiology 57:315-319.

Kohler J, Caravaca F, Carrasco L, Roldan A (2006). Contribution of Pseudomonas mendocina and Glomus intraradices to aggregates stabilisation and promotion of biological properties in rhizosphere soil of lettuce plants under field conditions. Soil Use and Management 22:298304.

Koocheki E, Zand E, Bannayan M, Rezvani Moghaddam P, Mahdavi Damghani A, Jami Al-Ahmadi M, Vesal SR (2004). Plant physiological ecology. Ferdowsi University of Mash had Press.

Lee G, Carrow RN, Duncan RR, Eiteman MA, Rieger MW (2008). Synthesis of organic osmolytes and salt tolerance mechanisms in Paspalum vaginatum. Environmental and Experimental Botany 63:1927.

Ma Y, Prasad MNV, Rajkumar M, Freitas H (2011). Plant growth promoting rhizobacteria and endophytes accelerate phytoremediation of metalliferous soils. Biotechnology Advances 29:248-258.

Manchanda G, Garg N (2011). Alleviation of salt-induced ionic, osmotic and oxidative stresses in Cajanuscajan nodules by AM inoculation. Plant Biosystems 145:88-97.

Marschner H, Dell B (1994). Nutrient uptake in mycorrhizal symbiosis. Plant and Soil 159:89-102.

Mar Vazquez M, Cesar S, Azcon R, Barea JM (2000). Interactions between arbuscular mycorrhizal fungi and other microbial inoculants (Azospirillum, Pseudomonas, Trichoderma) and their effects on 
124

microbial population and enzyme activities in the rhizosphere of maize plants. Applied Soil Ecology 15:261-272.

Mattioli R, Costantino P, Trovato M (2009). Proline accumulation in plants. Plant Signaling and Behavior 4(11):1016-1018.

Mittler R (2002). Oxidative stress, antioxidants and stress tolerance. Trends in Plant Science 7:405-410.

Nadeem SM, Zahir ZA, Naveed M, Arshad M, Shahzad SM (2006). Variatin in growth and ion uptake of maize due to inculation with plant growth promoting rhizobacteria under salt stress. Soil and Environment 25:78-84.

Navari Izzo F, Quartacci MF, Izzo R(1990). Water stress induced changes in protein and free amino acids in field grown maize and sunflower. Plant Physiology and Biochemistry 28:531-537.

Noctor G, Foyer CH (1998). Ascorbate and gutathione: keeping active oxygen under control. Annual Review of Plant Biology 49(1):249-279.

ParidaAK, Das A(2005). Salt toleranceandsalinity effects on plants: a review. Ecotoxicology and Environmental Safety 60:324349.

Parvaiz A, SatyawatiS (2008). Salt stress and phyto-biochemical responses of plants-a review. Plant, Soil and Environment 54:89-99.

Prasad TN, Sudhakar P, Sreenivasulu Y, Latha P, Munaswamy V, Raja Reddy K, Sreeprasad TS, Sajanlal PR (2012). Effect of nanoscale zinc oxide particles on the germination, growth and yield of peanut. Journal of Plant Nutrition 35:905-927.

Rurz-Lozano JM, Azcon R, Gomez M (1995). Effects of arbuscular mycorrhizal Glomus species on drought tolerance: physiological and nutritional plant responses. Applied and Environmental Microbiology 61:456-460.

Sannazzaro AI, Alberto E, Ruiz OA, Menendez B (2005). Influence of the arbuscular mycorrhizal fungus Glomus intraradices on the saline stress physiology of Lotus glaber.Lotus Newsletter 35:29-30.

Sato FH, Yoshioka T, Fujiwara H, Higashio A, Uragami S, Tokud A (2004). Physiological responses of cabbage plug seedlings to water stress during low temperature storage in darkness. Scientia Horticulturae 101:349-357.

Schat H, SharmaSS, Vooijs R (1997). Heavy metal induced accumulation of free proline in a metal tolerant and non-tolerant ecotype of Silene vulgaris. Physiologia Plantarum 101(3):477-482.

Seyed Sharifi R, Khavazi K (2011). Effects of seed priming with Plant Growth Promoting Rhizobacteria (PGPR) on yield and yield attributes of maize (Zea mays L.) hybrids. Journal of Food, Agriculture and Environment 9(384):496-500.
Shaharoona B, Arshad M, Zahir ZA (2006). Effect of plant growth promoting rhizobacteria containing ACC-deaminase on maize ( $Z e a$ mays $\mathrm{L}$.) growth under axenic conditions and on nodulation in mung bean (Vigna radiata L.). Letters in Applied Microbiology 42:155-159.

Sharma PN, Kumar N, Bisht SS (1994). Effect of zinc deficiency on chlorophyll content, photosynthesis and water relations of cauliflower plants. Photosynthetica 30:353-359.

Slama I, Messedi D, Ghnaya T, Savoure A, Abdelly C (2006). Effect of water deficit on growth and proline metabolism in Sesuvium portulacastrum. Environmental and Experimental Botany 56:231-238.

Sudhakar C, Lakshmi A, Giridara Kumar S (2001). Changes in the antioxidant enzyme efficacy in two high yielding genotypes of mulberry (Morus alba L.) under NaCl salinity. Plant Science 167:613-619.

Sultana N, Ikeda T, Itot R (1999). Effect of $\mathrm{NaCl}$ salinity on photosynthesis and dry matter accumulation in developing rice grains. Environmental and Experimental Botany 42:211-220.

Szabados L, Savoure A (2009). Proline: a multifunctional amino acid. Trends in Plant Science 15(2):89-97.

Van AF, Clijsters H (1990). Effects of metals on enzyme activity in plants. Plant, Cell and Environment 13(3):195-206.

Vessey JK (2003). Plant growth-promoting rhizobacteria as biofertilizers. Plant and Soil 255:571-586

Vivas A, Azcon R, Biro B, Barea JM, Ruiz-Lozano JM (2003). Influence of bacterial strains isolated from lead-polluted soil and their interactions with arbuscular mycorrhizae on the growth of Trifolium pratense $\mathrm{L}$. under lead toxicity. Canadian Journal of Microbiology 49:577-588.

Yamaguchi T, Blumwald E (2005). Developing salt-tolerant crop plants: challenges and opportunities. Trends in Plant Sciences 10(12):615-620.

Zago MP, Oteiza PI (2001). The antioxidant properties of zinc: Interactions with iron and antioxidants. Free Radical Biology and Medicine 31:266274.

Zarrouk O, Gogorcena Y, Gomez-Aparisi J, Betran JA, Moreno MA (2005). Influence of Almond peach hybrids root stocks on flower and leaf mineral concentration, yield, vigour of two peach cultivars. Scientia Horticulturae 106: 502-514. 